\title{
Influence of Yoga means on students' biological age indicators
}

\author{
Sereda I.O. ${ }^{1}$, Lavrin G.Z. ${ }^{1}$, Kucher T.V. ${ }^{2}$ \\ ${ }^{1}$ Ternopil Volodymyr Hnatiuk National Pedagogical University, Ukraine \\ ${ }^{2}$ Kremenets Regional Humanitarian and Pedagogical Academy of Taras Shevchenko, Ukraine
}

\begin{abstract}
Purpose:

to determine effectiveness of Yoga means' implementation in students' physical education programs.

Material:

in experiment 85 2nd year students participated, who were divided in control group (CG, n=43, 15 boys and 28 girls) and experimental group (EG, $n=42,17$ boys and 25 girls). Their calendar age was 18-19 years. By state of health all students were in main health group (without health problems). The researches were carried out during one academic semester and implied finding and comparing of students' biological age.

Results: $\quad$ by results of medical examination we registered 22 years as minimal biological age and 55 years as maximal. We found no students, whose biological age would correspond to calendar age. It was also found that systemic practicing of Yoga permits to keep proper level of students' health and increase their interest to physical exercises' practicing. It was proved that application of Yoga means approached students' biological age to calendar one.

Conclusions: introduction of Yoga complexes in physical education program will permit to sustain and improve students' biological indicators and positively influence on their health.

Keywords: fitness, Yoga, physical education, students, health.
\end{abstract}

\section{Introduction}

Development of modern fitness technologies opens wide possibilities for their application in students' physical education system. There have been found common tasks of fitness and physical education at higher educational establishment (HEE), which are fixed in its programs: health strengthening, rising of vital tonus, increase of general and special workability, training of physical qualities, formation of posture and correction of its defects, psycho-emotional improvement, resistance to everyday stresses [2, 23, 29, 34]. The mentioned tasks are rather important in the process of students studying and life activity.

One of popular directions of health related fitness is aerobic with psycho-regulating orientation (special direction), which includes Yoga exercises. Fitness Yoga, Yoga aerobic is effective training programs for physically active people, which facilitates harmony of body and mind. Regular and correctly organized trainings increase human activity, prevent from emersion of age diseases. Such trainings are one of the most important steps to reduction of biological age and possibility to prolong active and full fledged life $[15,17,30,51]$.

Regular practicing of Yoga exercises (asanas) helps to preserve muscular strength, tonus, density of bone tissue, joints' mobility as well as facilitates improvement of posture, balance, body weight reduction [35, 36, 40, 45]. Regular Yoga practicing, combined with breathing system Pranayama, can help to sustain normal blood circulation and respiratory system's functioning. Yoga practicing results in improvement of oxygen consumption indicators, breathing frequency, heart beats rate [33, 46, 48, 49]. Yoga is useful against stress, anxiety and depression and helps to sustain psychic health [7, 10, 20, 32].

Yoga practicing positively influences on all organism's systems: blood circulation, respiratory, digestive, endocrine, immune, nervous, muscular-skeletal apparatus. Besides, it slows ageing processes [7, 13, 14, 27].

New, non traditional and relevant as on to day physical

(C) Sereda I.O., Lavrin G.Z., Kucher T.V., 2017

doi:10.15561/20755279.2017.0307 education means are constantly implemented in students' physical education system $[2,5,16,38]$. The authors stress on the need in the following:

- Optimization of students' physical loads [24, 25] and process of physical exercises' mastering [8, 28];

- Consideration of individual perception of physical loads [21, 42] and students' biological age [18, 43];

- Proper control over physical loads [12, 31], body mass [27, 39, 44], and morphological functional indicators [41];

- Reduction of physiological stress's influence by means of Yoga [9];

- Rising of effectiveness of self-regulation training programs for sustaining the youth's health and successfulness [11, 37]; practicing of intervention (understanding of Yoga) in respect to weakening depression's after-effects [19];

- Study of Yoga's potential influence on youth's successfulness [22];

- Consideration of women organism's specificities in Yoga practicing [50];

For strengthening students' interest to physical exercises' practicing, specialists constantly seek new means for realization of physical education purposes. Yoga permits to realize health related trainings, envisaged by physical education program. That is why it is purposeful to offer it to students. Yoga exercises are interesting and demanded by most of students.

The relevance of the present study is conditioned by the following: wide potentials of modern fitness technologies in realization of physical education tasks; demand in introduction of such exercises in physical education process.

The purpose of this work is to determine effectiveness of Yoga means' implementation in students' physical education programs.

The purpose conditioned the tasks of this work:

1.Characterize the influence of the worked out training program on physiological indicators and subjective selfassessment of students' health that is reflected in biological age compliance with calendar age. 
2.Prove effectiveness of Yoga means for realization of students' physical education tasks and necessity of their implementation in academic program.

\section{Material and methods}

Participants: in experiment $852^{\text {nd }}$ year students participated, who were divided in control group (CG, $\mathrm{n}=43,15$ boys and 28 girls) and experimental group (EG, $\mathrm{n}=42,17$ boys and 25 girls). Their calendar age was 18 19 years. By state of health all students were in main health group (without health problems). All participants were informed and gave consent for participation in experiment.

Organization of the research: pedagogic experiment was carried out during one academic semester. At the beginning of experiment we found homogeneity of groups by analyzing physiological indicators and subjective selfassessment of own health that was reflected in biological age compliance with calendar age.

In experimental group physical education was fulfilled with application of Yoga means for beginners.

In control group trainings were conducted in compliance traditional physical education program $[2,5]$.

The program of trainings in EG was designed for 15 trainings (30 academic hours). The first two trainings stipulated the following: finding of students' biological age; familiarization with Yoga theory and regulations on exercises' fulfillment. For this purpose students were offered to look through video-materials on exercises' practicing. Besides, attention was accented on choice of training cloth.

The following trainings were of practical character. Great attention was paid to different kinds of breathing during Yoga trainings.

The students were offered to familiarize with the following kinds of breathing, which are used in Yoga practice:

- Full Yoga breathing, which implies lower (diaphragm) breathing: during inhale abdomen bulges a little; at exhale it retracts with simultaneous tensioning of pelvis muscles.

- Middle (chest) breathing: to be fulfilled by chest expansion and its lowering at exhale.

- Upper (collarbone) breathing: to be fulfilled by rising and lowering of collarbones.

Besides, kinds of breathing, which influence on energy flows and create balance in body and mind were used: quick alternation of inhales/exhales (bellows); breathing though alternating nostrils (inhale through right nostril and exhale through left nostril; breathing with step-by step pauses during inhale or exhale; breathing by mouth; breathing accompanied by vibrating sound during inhale or exhale(the sound of bee); breathing with quick strong exhale through nose; breathing with sucking-in stomach (20-30 breathing cycles) - "breathing of flame» [53].

Breathing exercises were constantly practiced: at the beginning of training; in final part for relaxation and in the process of exercises' fulfillment.

Practical trainings stipulated direct mastering and fulfillment of asanas. Fulfillment was started with twothree repetitions of one exercises' combination; gradually quantity of repetitions was increased up to 5-6. First (at one lesson) students were offered to fulfill one - two combinations of exercises. Further, their quantity also increased with students' organism's adaptation to the offered loads.

For example, at first practical classes students fulfilled initial classic complex «Surya Namaskara» («The Sun God»), which consisted of 12 asanas (see fig. 1). They shall be fulfilled in strict sequence and with certain breathing rhythm.

Fulfillment of this complex is accompanied by uniform and smooth breathing by the following scheme: $1^{\text {st }}$ asana - inhale - exhale; $2^{\text {nd }}-$ inhale; $3^{\text {rd }}-$ exhale; $4^{\text {th }}$ asana inhale; $5^{\text {th }}$ - exhale; $6^{\text {th }}-$ inhale-exhale; $7^{\text {th }}$ asana - inhale; $8^{\text {th }}-$ exhale; $9^{\text {th }}-$ inhale; $10^{\text {th }}$ asana - exhale; $11^{\text {th }}-$ inhale and $12^{\text {th }}$ asana - exhale 14 ].

Further asanas changed by other or their sequence

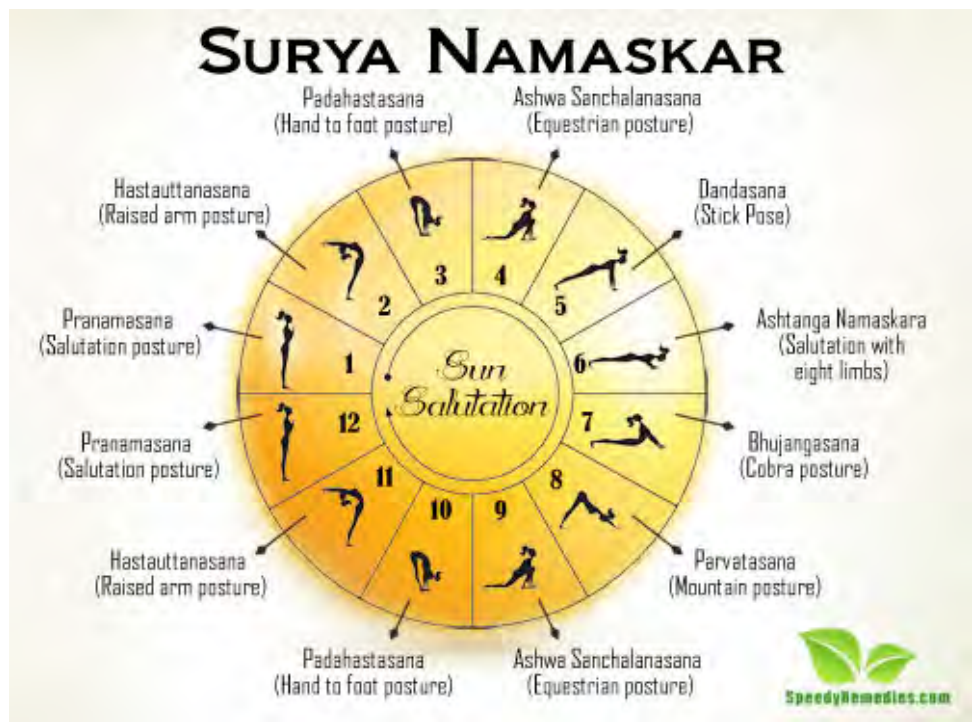

Fig. 1. Surya Namaskar "Salutations to the Sun» complex [53]. 
was changed. Exercises' complexes included: Anantasana (Side-Reclining Leg Lift); Adho mukha shvanasana (Downward Facing Dog); Ardha Matsyendrasana (Half Spinal Twist Pose); Ardha Chakrasana (Half Wheel Pose); Baddha Konasana (Bound Angle Pose) [6].

Effectiveness of experimental program of the offered by us exercises was ensured by appropriate pedagogic conditions of their realization: creation of positive psychoemotional atmosphere at the account of correct breathing and body relaxation as well as musical accompaniment (slow music with nature motives, if trainings were conducted indoors); outdoors trainings; regular exercises' practicing at home.

For realization of the last conditions students were offered to look through video-materials (internet video as an example for home exercises' practicing). Thus, habit to independent trainings was stimulated [52].

The methods of the research: theoretical analysis and generalization of scientific-methodic literature data, oral questioning, pedagogic experiment, physiological methods, determination of biological age as per [1], pedagogic observation and methods of mathematical statistic.

At the beginning we conducted stating experiment for determination of students' biological age. It is known that relation of calendar age to biological age is rather informative indicator of a person's health.

Biological age is combined conception, reflecting individual, actually achieved level of morphological functional mature of separate tissues, organs, systems and organism in the whole. Biological age is real age of human body. Biological age (BA) is determined with the help of different methodic. There are rather complex variants with application of modern medical instrumentation. We chose methodic of V.P. Voytenko [1] for determination of biological age. For boys we used the following formula:

$$
\begin{gathered}
B A=44.3+0.68 \cdot S A H+0.40 \cdot B P S-0.22 \cdot B P D- \\
0.22 \cdot B P P-0.004 \cdot V C L-0.11 \cdot B P I+0.08 \cdot B P E-0.13 \\
\cdot S B
\end{gathered}
$$

For girls:

$$
\begin{gathered}
B A=17.4+0.82 \cdot S A H-0.005 \cdot B P S+0.16 \cdot B P D+ \\
0.35 \cdot B P P-0.004 \cdot V C L+0.04 \cdot B P I-0.06 \cdot B P E- \\
0.11 \cdot S B
\end{gathered}
$$

Where BPS - blood pressure systolic, mm/merc.col.; BPD - blood pressure diastolic, mm/merc.col.; BPP pulse pressure, difference between systolic and diastolic pressure, mm/merc.col.; VCL - vital capacity of lungs, $\mathrm{ml}$; BPI - breathing pause at inhale, sec.; BPE - breathing pause at exhale, sec.; SB - static balancing on left foot with closed eyes (barefoot), arms straightened along torso; SAH- self-assessment of health by questioning, points.

Self-assessment of health:

1. How do you estimate your health, comparing with the health of your peers? Excellent (1), good (2), satisfactory (3), bad (4).
2. How do you estimate your current health? Excellent (3), good (2), satisfactory (1), bad (0), no answer (-).

3. Do you think, your health is excellent (1), good (2), satisfactory (3), bad (4)?

4. Do you feel yourself healthy? Yes (1), No (2).

5 . How do you estimate your health to-day? Very good (1), good (2), so-so (3), satisfactory (4), bad (5).

6. Can you say that during last 12 months your health has been good (1), more or less satisfactory (2), so-so (3)?

Statistical analysis: the results were process by methods of variation statistic with finding of mean arithmetic (M), arithmetic error (m), mean square deviation $(\sigma)$, confidence of differences by Student's t-test (p).

\section{Results}

At the beginning of experiment we did not find any noticeable distinctions between students of both groups (p>0.05).

Physiological indicators of EG and CG students did not differ practically $(\mathrm{p}>0.05)$. Mean value of cardiovascular system's functioning was registered in the range of 119/72 bpm (boys) and 101/60 bpm (girls). In most of students this indicators is characterized by reduction of blood pressure. VCL of boys and girls also was lower than normal. It was in average $3000 \mathrm{ml}$ and $2500 \mathrm{ml}$. Indicators of breathing pause in both groups' girls was within 45 sec. at inhale and $20 \mathrm{sec} /$ at exhale. Indicators of boys were: 50 sec. at inhale and $25 \mathrm{sec}$. at exhale. These indicators were the only, which were the most approached to the norm. Girls kept balance with closed eyes in average during 42 sec/ and boys - 19 sec.

Analysis of EG and CG students' self-assessment of health before experiment sowed their indifferent attitude to own health and not understanding the available problems. $55 \%$ of students thin that they have good health. Results of physiological examination prove the opposite. Only in $45 \%$ of students self assessment coincided with actual indicators of their health.

By results of medical examination the lowest biological age was registered as 22 years and the highest as 55 years. We did not find any student, whose biological age would coincide with calendar age.

It should be noted that the offered by us methodic revealed students' great interest to determination of their biological age. Such methodic was offered for the first time. For this purpose, for finding of physical exercises' influence on organism we used expressed assessment of health level by methodic of G.L. Apanasenko and analysis of students' physical fitness dynamic [3, 4]. Application of new methodic facilitated increased of interest to trainings. Besides, it stimulated students' wish to approach the found indicators to calendar age.

After Yoga means' implementation in physical education process, we fulfilled repeated estimation of students' biological and calendar ages' correspondence. Application of Yoga trainings' experimental program positively influenced on improvement the detected earlier indicators of EG students' biological age $(\mathrm{P}<0.05)$. 
Mean indicators of EG students' blood pressure reduced up to $118 / 73 \mathrm{bpm}$ (in CG - 120/65 bpm) in boys and 110/65 bpm (in CG -102/55 bpm) in girls. A little better became VCL and breathing pause indicators in EG. After experiment, VCL in EG boys was registered within $4000 \mathrm{ml}$, and in girls - $3000 \mathrm{ml}$. In CG this indicators practically did not change and was $3100 \mathrm{ml}$ (boys) and $2400 \mathrm{ml}$ (girls). EG boys improved duration of pause at inhale up to average value $60 \mathrm{sec}$. and at exhale - up to 35 sec. Girls improved their mean indicators up to $50 \mathrm{sec}$. and 25 sec. accordingly. In CG time of breathing pause did not change (girls - $45 \mathrm{sec}$ at inhale and $20 \mathrm{sec}$. at exhale and boys $50 \mathrm{sec}$. at inhale and $25 \mathrm{sec}$. at exhale).

Such changes in physiological indicators we connect with constant accenting of attention on correct breathing during exercises' fulfillment that positively influenced on students' cardio-vascular and respiratory systems.

Yoga exercises' practicing positively influenced on static balancing indicators. At the end of experiment EG students improved the time of balancing: girls - up to 53 sec. and boys - up to $28 \mathrm{sec}$. In CG (boys and girls) this indicators practically did not change (20 sec. and 43 sec.).

Analysis of health self assessment witnesses that in EG students' self-feeling is better ( $60 \%$ assessed as excellent, 35\% - good and 5\% - satisfactory). In CG most of students assessed their health as good, though physiological indicators showed the opposite. It witnesses that EG students acquired more conscious attitude to own health.

In EG students the lowest indicator of biological age was 20 years and the highest - 43 years (indicators reduced). In CG the lowest indicator of biological age was 22 years and the highest -50 .

\section{Discussion}

Results of our research showed effectiveness of Yoga trainings for successful realization of tasks, envisaged by physical education programs [2, 5]. The purposefulness of the offered complexes meet students' interest to such physical exercises that was proved by results of questioning.

Analysis of some physiological indicators proved the data that Yoga practicing positively influences on cardio-vascular and respiratory systems [14, 19, 48, 49].
Improvements of students' static balancing time coincides with scientists' opinion that regular physical exercises (asanas) help to presreve muscular strength, tonus and harmony of the whole body [22, 35, 37].

Results of health self-assessment prove that regular and correctly organized Yoga practicing increase activity. They positively influence on self-feeling, reduce the threshold of morbidity and stress [7,9, 23, 51].

Our study also proved that Yoga practicing is one of the most important steps to biological age reduction and to possibility to prolong active and full fledged life [15, $30,51]$. The offered in the worked out program exercises actually positively influenced on students' biological age indicators.

Special aspects of Yoga exercises' mastering are the novelty. In the experiment Yoga was a new and unknown kind of physical loads for students. It facilitated its mastering and independent fulfillment of exercises.

It was found that implementation and application of methodic for biological age determination facilitate increasing of interest to own health as well as understanding of physical education importance in solution of this task.

By results of students' biological age correspondence to calendar age we found that introduction of Yoga complexes in physical education program would permit to sustain and improve students' physiological indicators and positively influence on students' health.

\section{Conclusions}

Implementation of Yoga trainings experimental program improved EG students' biological age $(\mathrm{P}<0.05)$. Especially respiratory system and static balancing indicators of EG boys and girls were improved. Besides, in EG student's interest to physical education classes and desire for independent exercises' practicing increased.

Results of our researches point at positive influence of Yoga on students' organism physiological indicators and on their interest to such exercises. That is why it is purposeful to introduce Yoga in physical education program.

\section{Conflict of interests}

The authors declare that there is no conflict of interests.

\section{References}

1. Vojtenko VP, Tokar AV, Rudaia ES. Metodika opredeleniia biologicheskogo vozrasta [Methodic of biological age determination]. Voprosy gerontologii, 1989;11:9 - 16. (in Russian)

2. Lavrin GZ. Robocha programa «Fizichne vikhovannia» [Working program "Physical education"], Ternopil: TNPU; 2015. (in Ukrainian)

3. Lavrin GZ, Sereda IO. Riven' zdorov'ia studentiv - vagomij chinnik obov'iazkovikh zaniat' $\mathrm{z}$ fizichnogo vikhovannia u VNZ [Students' health level as an important factor of compulsory physical education classes at HEE]. Valeologiia: suchasnist' i majbutnie, 2016;20:104-108. (in Ukrainian)

4. Sereda I, Lavrin G. Dinamika rivnia fizichnoi pidgotovlenosti studentiv Ternopil's'kogo nacional'nogo pedagogichnogo universitetu im. V. Gnatiuka [Dynamic of physical fitness level of Ternopil Volodymyr Hnatiuk National Pedagogical University students]. Moloda sportivna nauka Ukraini, 2016;20(1,2):315-320. (in Ukrainian)

5. Sereda IO. Robocha programa «Fizichne vikhovannia» [Working program "Physical education”], Ternopil: TNPU; 2016. (in Ukrainian)

6. Khatkha joga [Khatkha Yoga]. [internet]. 2017 [cited 2017 Mar 24]. Available from: http://newyogalife.com

7. Anon. Vegetarians Live Longer. [internet]. 2017 [cited 2017 Mar 24]. Available from: http://www.healingcancernaturally. com/vegetarians-live-longer.html

8. Arziutov G, Iermakov S, Bartik P, Nosko M, Cynarski WJ. The use of didactic laws in the teaching of the physical elements involved in judo techniques. Ido Movement for 
Culture, 2016;16(4):21-30. doi:10.14589/ido.16.4.4

9. Bamber MD, Schneider JK. Mindfulness-based meditation to decrease stress and anxiety in college students: A narrative synthesis of the research. Educational Research Review. 2016;18:1-32.

10.Bartnovskay LA, Kudryavtsev MD, Kravchenko VM, Iermakov SS, Osipov AYu, Kramida IE. Health related applied technology of special health group girl students' physical training. Physical education of students, 2017; 21(1): 4-9. doi:10.15561/20755279.2017.0101

11.Bergen-Cico D, Razza R, Timmins A. Fostering SelfRegulation Through Curriculum Infusion of Mindful Yoga: A Pilot Study of Efficacy and Feasibility. Journal of Child and Family Studies. 2015;24(11):3448-61.

12.Bliznevsky AA, Kudryavtsev MD, Iermakov SS, Jagiello W. Formation of active-effective attitude of 12-13 years' judo athletes to sports functioning in competition period. Archives of Budo. 2016;12:101-15.

13.Butzer B, LoRusso A, Shin SH, Khalsa SBS. Evaluation of Yoga for Preventing Adolescent Substance Use Risk Factors in a Middle School Setting: A Preliminary GroupRandomized Controlled Trial. Journal of Youth and Adolescence. 2017;46(3):603-32.

14.Chaya MS, Kurpad AV, Nagendra HR, Nagarathna R. The effect of long term combined yoga practice on the basal metabolic rate of healthy adults. BMC Complement Altern Med, 2006;6:28-32.

15.Desikachar TKV, Cravens RH. Health, healing and beyond: yoga and the living tradition of Krishnamacharya. New York: Aperture; 1998

16.Drogomeretsky VV, Kopeikina EN, Kondakov VL, Iermakov SS. Adaptation of Ruffier's test for assessment of heart workability of students with health problems. Pedagogics, psychology, medical-biological problems of physical training and sports, 2017; 21(1): 4-10. doi:10.15561/18189172.2017.0101

17.Druz VA, Iermakov SS, Artemyeva GP, Puhach YI, Muszkieta R. Individualization factors of students' physical education at modern stage of its realization. Physical education of students, 2017;21(1):10-16. doi:10.15561/20755279.2017.0102

18.Druz VA, Iermakov SS, Nosko MO, Shesterova LYe, Novitskaya NA. The problems of students' physical training individualization. Pedagogics, psychology, medicalbiological problems of physical training and sports, 2017; 21(2): 4-12. doi:10.15561/18189172.2017.0201

19.Falsafi N. A Randomized Controlled Trial of Mindfulness Versus Yoga: Effects on Depression and/or Anxiety in College Students. Journal of the American Psychiatric Nurses Association. 2016;22(6):483-97.

20.Fishbein D, Miller S, Herman-Stahl M, Williams J, Lavery B, Markovitz L, et al. Behavioral and Psychophysiological Effects of a Yoga Intervention on High-Risk Adolescents: A Randomized Control Trial. Journal of Child and Family Studies. 2016;25(2):518-29.

21.Gaskov AV, Kuzmin VA, Kudryavtsev DM, Iermakov SS. Successfulness of general and special physical qualities' development on different stage of students-boxers' training. Physical Education of Students. 2016;20(1):4-11. 10.15561/20755279.2016.0101

22.Hagins M, Rundle A. Yoga Improves Academic Performance in Urban High School Students Compared to Physical Education: A Randomized Controlled Trial. Mind Brain and Education. 2016;10(2):105-16.

23.How to Reduce Your Biological Age and Feel 10 Years Younger! Nine Most Important Steps to Reducing Your
Biological Age. [internet]. 2017 [cited 2017 Mar 24]. Available from: http://www.rehabcorp.com.au/how-toreduce-your-biological-age-and-feel-10-years-younger/

24.Iermakov SS, Arziutov GN, Jagiello W. Quick training of students to judo techniques. Archives of Budo. 2016;12:1524

25.Iermakov SS, Podrigalo LV, Jagiello W. Hand-grip strength as an indicator for predicting the success in martial arts athletes. Archives of Budo. 2016;12:179-86.

26.Innes KE, Bourguignon C, Gill Taylor A. Risk Indices Associated with the Insulin Resistance Syndrome, Cardiovascular Disease, and Possible Protection with Yoga: A Systematic Review. Journal of the American Board of Family Medicine. 2005; 18(6):491-519.

27.Jagiello W. Differentiation of the body composition in taekwondo-ITF competitors of the men's Polish national team and direct based athletes. Archives of Budo. 2015;11:329-38.

28.Khudolii OM, Ivashchenko OV, Iermakov SS, Rumba OG. Computer simulation of Junior gymnasts' training process. Science of Gymnastics Journal, 2016;8(3):215-228.

29.Kopeikina EN, Drogomeretsky VV, Kondakov VL, Kovaleva MV, Iermakov SS. Modification of harvard step-test for assessment of students' with health problems functional potentials. Physical Education of Students. 2016;20(4):4450. doi:10.15561/20755279.2016.0405

30.Koubova J, Guarente L. How does calorie restriction work? Genes Dev, 2003;17:313-321.

31.Kozina ZL, Iermakov SS, Kadutskaya LA, Sobyanin FI, Krzeminski M, Sobko IN, Ryepko OA. Comparative characteristic of correlation between pulse subjective indicators of girl students' and school girls' reaction to physical load. Physical Education of Students. 2016;20(4):2434. doi:10.15561/20755279.2016.0403

32.Kudryavtsev MD, Kramida IE, Iermakov SS, Osipov AY. Development dynamic of healthy life style personality component in relatively healthy students. Physical Education of Students. 2016;20(6):26-33. doi:10.15561/20755279.2016.0603

33.Kudryavtsev MD, Kramida IE, Iermakov SS. Influence of studying in higher educational establishment on students' harmful computer habits. Physical Education of Students. 2016;20(5):17-23. doi:10.15561/20755279.2016.0503

34.Kudryavtsev MD, Kramida IE, Kuzmin VA, Iermakov SS, Cieslicka M, Stankiewicz B. Influence of study in hee on ubiquity and strength of students' computer gambling. Physical Education of Students. 2016;20(3):13-22. doi:10.15561/20755279.2016.0302

35.Maharishi Mahesh Yogi: The science of being and art of living. Los Angeles: International SRM Publications; 1969.

36.Mahlo L, Tiggemann M. Yoga and positive body image: A test of the Embodiment Model. Body Image. 2016;18:13542.

37.Nowak ALV, DeGise J, Daugherty A, O’Keefe R, Seward S, Setty S, et al. Prevalence and Predictors of Complementary and Alternative Medicine (CAM) Use Among Ivy League College Students: Implications for Student Health Services. J Am Coll Health. 2015;63(6):362-72.

38.Osipov AY, Kudryavtsev MD, Kramida IE, Iermakov SS, Kuzmin VA, Sidorov LK. Modern methodic of power cardio training in students' physical education. Physical Education of Students. 2016;20(6):34-9. doi:10.15561/20755279.2016.0604

39.Osipov AYu, Kudryavtsev MD, Gruzinky VI, Kramida IE, Iermakov SS. Means of optimal body mass control and obesity prophylaxis among students. Physical education of students, 
2017; 21(1): 40-45. doi:10.15561/20755279.2017.0107

40.Park CL, Riley KE, Bedesin E, Stewart VM. Why practice yoga? Practitioners' motivations for adopting and maintaining yoga practice. Journal of Health Psychology. 2016;21(6):887-96.

41.Podrigalo LV, Galashko M N, Iermakov SS, Rovnaya OA, Bulashev AY. Prognostication of successfulness in armwrestling on the base of morphological functional indicators' analysis. Physical education of students, 2017; 21(1): 46-51. doi:10.15561/20755279.2017.0108

42.Podrigalo LV, Iermakov SS, Alekseev AF, Rovnaya OA. Studying of interconnections of morphological functional indicators of students, who practice martial arts. Physical Education of Students. 2016;20(1):64-70. doi:10.15561/20755279.2016.0109

43.Pryimakov AA, Eider E, Nosko MO, Iermakov SS. Reliability of functioning and reserves of system, controlling movements with different coordination structure of special health group girl students in physical education process. Physical education of students, 2017; 21(2): 84-89. doi:10.15561/20755279.2017.0206

44.Sawczyn S, Mishchenko V, Moska W, Sawczyn M, Jagiello M, Kuehne T, et al. Strength and aerobic training in overweight females in Gdansk, Poland. Open Medicine. 2015;10(1):152-62.

45.Siegel P, Goncalves AV, da Silva LG, Bartolomei L, Barreto MJ, Furlanetti MR, et al. Yoga and health promotion, practitioners' perspectives at a Brazilian university: A pilot study. Complementary Therapies in Clinical Practice.
2016;23:94-101.

46.Skurikhina NV, Kudryavtsev MD, Kuzmin VA, Iermakov SS. Fitness yoga as modern technology of special health groups' girl students' psycho-physical condition and psychosocial health strengthening. Physical Education of Students. 2016;20(2):24-31. doi:10.15561/20755279.2016.0204

47.Surya Namaskar. Salutations to the Sun. [internet]. 2017 [cited 2017 Mar 24]. Available from: http://www.harekrsna. de/surya/surya-names.htm

48.Telles S, Nagarathna R, Nagendra HR: Autonomic changes during OM Meditation. Indian J Physiol and Pharmacol. 1995;39:418-20.

49.Telles S, Nagarathna R, Nagendra HR: Breathing through a particular nostril can alter metabolic and autonomic activities. Indian J Physiol Pharmacol. 1994;38:133-37.

50.Tsai SY. Effect of Yoga Exercise on Premenstrual Symptoms among Female Employees in Taiwan. International Journal of Environmental Research and Public Health. 2016;13(7):34-40.

51.Yang K. A Review of Yoga Programs for Four Leading Risk Factors of Chronic Diseases. Evidence-Based Complementary and Alternative Medicine. 2007;4(4):487-91.

52.Yoga home. Complex Michael Roach. [internet]. 2017 [cited 2017 Mar 24]. Available from: https://ok.ru/ video/10987308525

53.Yoga Links. Pranayama. [internet]. 2017 [cited 2017 Mar 24]. Available from: http://www.yogalinks.net/pranayama/ pranayama.html

Information about the authors:

Sereda I.O.; http://orcid.org/0000-0002-1517-5618; seredaira85@mail.ru; Ternopil Volodymyr Hnatiuk National Pedagogical University; 2 Maxyma Kryvonosa str., Ternopil, 46027, Ukraine.

Lavrin G.Z.; http://orcid.org/0000-0001-6750-8421; maximiv@bigmir.net; Ternopil Volodymyr Hnatiuk National Pedagogical University; 2 Maxyma Kryvonosa str., Ternopil, 46027, Ukraine.

Kucher T.V.; http://orcid.org/0000-0001-9806-2821; tatochkak@ukr.net; Kremenets Regional Humanitarian and Pedagogical Academy of Taras Shevchenko; Per. Lyceumsky, 1, Kremenets, Ternopil region, 47003, Ukraine.

Cite this article as: Sereda IO, Lavrin GZ, Kucher TV. Influence of Yoga means on students' biological age indicators. Physical education of students, 2017;21(3):140-145. doi:10.15561/20755279.2017.0307

The electronic version of this article is the complete one and can be found online at: http://www.sportedu.org.ua/index.php/PES/issue/archive

This is an Open Access article distributed under the terms of the Creative Commons Attribution License, which permits unrestricted use, distribution, and reproduction in any medium, provided the original work is properly cited (http://creativecommons.org/licenses/by/4.0/deed.en).

Received: 11.04 .2017

Accepted: 25.04.2017; Published: 10.05.2017 